DOI: https://doi.org/10.31933/dijms.v2i4

Received: 26 October 2020, Revised: 7 March 2021, Publish: 11 March 2021

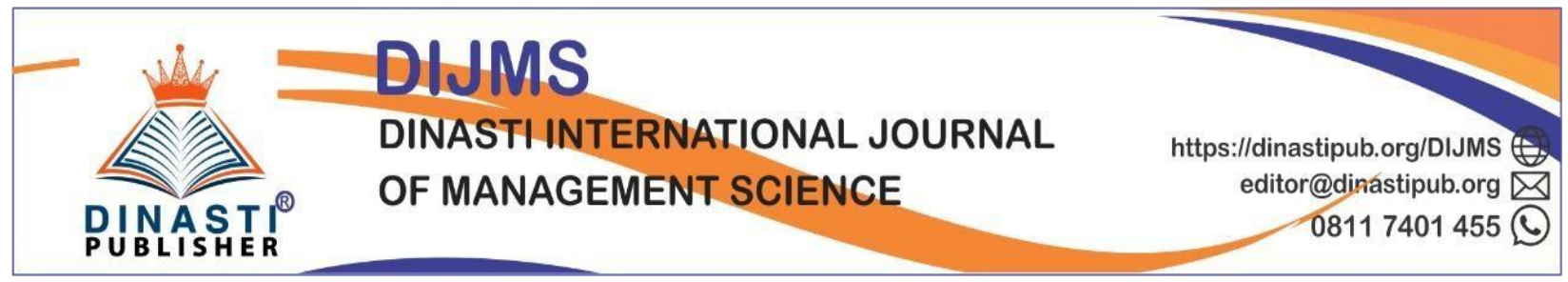

\title{
DEVELOPMENT AND APPLICATION OF APPROPRIATE TECHNOLOGY TO RECYCLE WASTE PERFORMED
}

\author{
I Gusti Ayu Arwati ${ }^{1}$, Euis Nina Saparina Yuliani ${ }^{2}$, Nur Endah Retno Wuryandari ${ }^{3}$, Diana \\ Lutfiana 4 \\ Universitas Mercu Buana, Jakarta, Indonesia, ayuarwati@ mercubuana.ac.id \\ 2) \\ Universitas Mercu Buana, Jakarta, Indonesia, nina.yuliani@ mercubuana.ac.id \\ 4) \\ Universitas Mercu Buana, Jakarta, Indonesia, diana.lutfiana@ mercubuana.ac.id
}

\section{Corresponding Author: I Gusti Ayu Arwati}

Abstract: The program of development and application of appropriate technology to recycle waste is executed by SMEs Bank Sampah (Waste Bank) Bumi Hijau Cemerlang Desa Suradita Tanggerang. The team was established since 2015. The management of this waste bank foundation is always energetic and productive so as they are competent to collect $200 \mathrm{~kg}$ inorganic waste (plastic and paper) in one week. On the other side, they did recycling liquid fertilizer from organic waste by using the used composter. This action is performed by realizing the fact that household waste matter gets heaped and malignant toward s environment. The are problems faced by the team. Providing learning assistance in the form of appropriate technology tools and how to use them. In order to ensure the successful of this program, evaluation is carried out in every step of the program's development.

Keywords: Waste Product Recycling, Build The Sale Value Of Waste, Appropriate Technology

\section{INTRODUCTION}

In reality, in 2019 the entrepreneurs of micro business, small and medium (SMEs) were preconcert facing politic democracy party and global economic competition in ill will. This led into real challenge also opportunity for SMEs in order to greater and empower the economic side. So that they are able to develop themselves turning into tough and independent business on technology basis and local culture as the form of SMEs face power. On the other hand, SMEs will deal with free trade in 2020, where there were agreed that free trade will be enforced in developing countries including Indonesia (Dika Agus.2018). 
Condition of economic growth nowadays is still in slack category, however it is reflected by the economic growth in 2016 reaching 5,25 percent and 5,07 percent on 2017, meanwhile 5,27 percent on 2018. In 2019, the economic growth was expected to increase so that it could reach 5,3 percent (tribunnews.com 2018).

The said background indicates that SMEs has strategic role in Indonesian economic growth, especially in greater the local economic growth in rural areas. Several characteristics of SMEs are:

1. Can become labor-intensive business which is expected to absorb the workforce in rural areas, 2. Can be initiated with relatively small amount of capital (3) Can use relatively simple technology or utility. One of the most vital endeavors of this UMKM is that they recycle waste to gain economic value.

\section{Analytical Situation}

The government of Tangerang city, Banten, has established waste bank program which was intended to give economic value to the waste and educate local people not to litter. This program was executed because regional government faced waste as scourge. For the activity itself, if it is implemented in mass and more serious, then it can prop up the economy of society (Lehman Gleen, 2004). Based on Dinas Lingkungan Hidup (DLH/environmental Service) of Tangerang city, waste bank has fecund 361 branches (Tangerangnews.com.2019)

\section{The profile of SMEs Bumi Hijau Cemerlang Waste Bank}

One of the waste banks named Bumi Hijau Cemerlang, located in Suradita village, Cisauk sub-district, Tanggerang district. The result of survey and interview conducted by Mercu Buana lecturer team with the leader of waste bank team, it was stated that Bumi Hijau Cemerlang waste bank has established since 2015, However the village head had this group officially inaugurated on 2019 by issuing management decree (Number 2 Year 2019) for Suradita village based on Act Law article 5 number 18 Year 2008 regarding to waste management with the organization structure;

The process to collect waste is conducted by each home resident by separating inorganic waste and organic waste to be then collected by waste bank team. The next process organized by waste bank team is weighing the waste, however for the inorganic waste, will be recorded in each resident's card.

The inorganic waste then separated by the waste bank team to be then sold to the scavengers. According to the report from the leader of waste bank team, $300 \mathrm{~kg}$ until $500 \mathrm{~kg}$ waste can be collected within 2 weeks and sold for IDR 200 per kg which is relevantly cheap. The team drives at recycling inorganic and organic waste in order to make them useful things and give them economic value. The waste bank team has made inorganic waste into liquid fertilizer by using composter. However the survey result shows that the composter is not proper enough in condition. From the 6 location spots that are managed by the waste bank team, there is only one composter (can be seen on picture 1), that is the reason why a lot of organic waste piles up and not fully handled which led into unhealthy environment and endanger the surrounding people. Moreover, the liquid fertilizer produced using composter is still not conducted optimally due to lack of composter. The quantity of composter has to be added along with modern design so that they can produce proper liquid fertilizer quality as they are intended to be marketed. All this time, the liquid fertilizer is limited in amount and used in internal matter by the member of 
waste bank team. The stack of organic waste from households has to be handled quickly so it does not become hazardous towards environment and the surrounding people.

\section{The Potentiality and Opportunity of Waste Recycle of SMEs}

The definition of recycle process here means reuse the secondhand or the unused items to become multifunction or to be trading commodity. This endeavor is intended to reduce or solve environmental pollution caused by littering. The garbage littering pollutes the environment to be dirty even clog the conduit. Besides, the waste stack can stimulate various diseases.

Inorganic waste especially plastic takes long time to decompose, it is different from organic waste which decomposes well so it is used as natural fertilizer. One of the examples is vegetable remnants. This is the reason why one of the ultimate alternative ways is to recycle the unused items that are categorized as inorganic waste to be managed properly.

The main process is initiated by separating the trashes for the inorganic waste, organic waste, leftover food and plastic. This action is expected to solve environmental pollution and open new opportunities for waste bank team in Suradita village to start new job field. Besides overcoming the environmental pollution issue, this is also intended to greater national economic as it reduces unemployed people in Suradita village (RW 09), especially the housewives who are the members of Family Welfare Movement (Family Welfare Program/Organization). The unused items are recycled as various handmade craft products such as flower vases made from plastic bottles, tissue boxes made from paper, etc. Processing the unused items to be recycled as multifunction products is notably needed to conduct because people ought to prevent environmental pollution and encourage the movement to love the life we live in.

There are a lot of benefits that can be obtained by doing recycle. Several of them are: (1) Opening new job field, (2) Increasing income of society, (3) Overcoming clean and healthy environment.

\section{The Problems Faced by the Waste Bank Team}

Based on the analysis of situation described above, the issues faced by the waste bank team are summarized on the table 1 as below;

Table 1 The Problems of Waste Bank Team

\begin{tabular}{|c|c|c|}
\hline No. & Problem & Description \\
\hline 1. & $\begin{array}{l}\text { Developing the inorganic wastes like plastic, paper, etc. to } \\
\text { create handmade craft products. }\end{array}$ & $\begin{array}{l}\text { The Bumi hijau Cemerlang } \\
\text { waste bank team who collects } \\
\text { inorganic waste still cannot } \\
\text { create handmade craft products } \\
\text { due to lack of understanding, } \\
\text { skill or experience to process so } \\
\text { then the stock of inorganic } \\
\text { waste is sold to the sca venger } \\
\text { with low price and has less } \\
\text { benefit. }\end{array}$ \\
\hline 2. & $\begin{array}{l}\text { Mana gement of administration and product marketing of } \\
\text { plastic wa ste handmade craft products and fertilizer. }\end{array}$ & $\begin{array}{l}\text { The waste bank team Bumi } \\
\text { Hijau Cemerlang has lack of } \\
\text { knowledge related to } \\
\text { administration skill, } \\
\text { organization management and } \\
\text { marketing process. }\end{array}$ \\
\hline
\end{tabular}




\begin{tabular}{|ll|}
\hline 3. The solid organic waste issue that is partially overcame and \\
$\begin{array}{ll}\text { not yet handled maximum due to lack of composter(the } \\
\text { existing composter also in improper condition, need to add } \\
\text { more in a vailability) }\end{array}$ & $\begin{array}{l}\text { The organic waste issue is not } \\
\text { yet solved due to the available } \\
\text { composter is only one improper } \\
\text { item. Thus the team need } \\
\text { composter that is more modern, } \\
\text { affordable and effective so then } \\
\text { they are able to make good } \\
\text { quality liquid fertilizer. }\end{array}$ \\
\hline
\end{tabular}

Source : Pilot Survey Researcher, 2019

\section{LITERATURE REVIEW}

In principle, the development of technology uses a composter tool which is based on the process of decomposing organic matter that occurs naturally. The digestion process is optimized in such a way that composting can run faster and more efficiently. Composting technology is currently very important because it is used to solve the problem of organic waste, such as to solve the problem of waste in big cities, organic and household industrial waste, as well as agricultural and plantation waste.

Making liquid fertilizer with the help of the fermentation activator EM4, where this activator is a material that contains several microorganisms which are very useful in the composting process. These activators also have other benefits, such as improving soil physical, chemical and biological properties, providing good nutrients, and making plants healthy. Therefore, it is necessary to continue to develop appropriate technology in designing a simple composter to make it easier to use to solve solid waste problems. . Processing waste into liquid fertilizer is one of the right an swers as part of the $3 \mathrm{R}$ component (reduce, reuse, and recycle). This will bring great benefits because liquid fertilizers have started to be applied frequently since the development of hydroponic plants (Nurjazuli, et al. 2016 and Hasibuan et al. 2017)

Based on the described situation, thus the solution is to provide learning and socialization by inviting the experts of handmade craft products to develop inorganic plastic waste recycle. Besides that, the thing that need to be highlighted are learning management skill to gain the economic value of the recycled products, from both inorganic waste (handmade craft prod ucts) and organic waste (liquid fertilizer) also designing and creating the composter machine to overcome the wet solid waste issue. The core of identified issues of this program, thus the team search concepts of alternative solution which are offered are below on Table 2;

Table 2 The Offered Solution Concepts

\begin{tabular}{|lll|}
\hline No. & Solution & External Target \\
\hline $\begin{array}{l}\text { Providing learning and socialization to develop } \\
\text { inorganic waste (plastic, paper, etc.(by creating several } \\
\text { handmade craft products). The learning will be } \\
\text { conducted by lecturer team and college students of } \\
\text { Mercubuana University, supervised by special trainer. }\end{array}$ & $\begin{array}{l}\text { The a vailability of creative learning } \\
\text { module of handmade craft products } \\
\text { from inorganic waste. } \\
\text { The waste bank's team ability } \\
\text { improvement in majoring the } \\
\text { handmade craft technique skill. }\end{array}$ \\
\hline $\begin{array}{l}\text { Providing product selling value power management } \\
\text { learning and give training to the accounting team }\end{array}$ & $\begin{array}{l}\text { The availability of simple accounting } \\
\text { administration so that the financial } \\
\text { report of Bumi Hijau Cemerlang waste } \\
\end{array}$ & $\begin{array}{l}\text { team can be managed accurately, } \\
\text { reliable and on time also the financial } \\
\text { condition, amount of benefit and }\end{array}$ \\
\hline
\end{tabular}




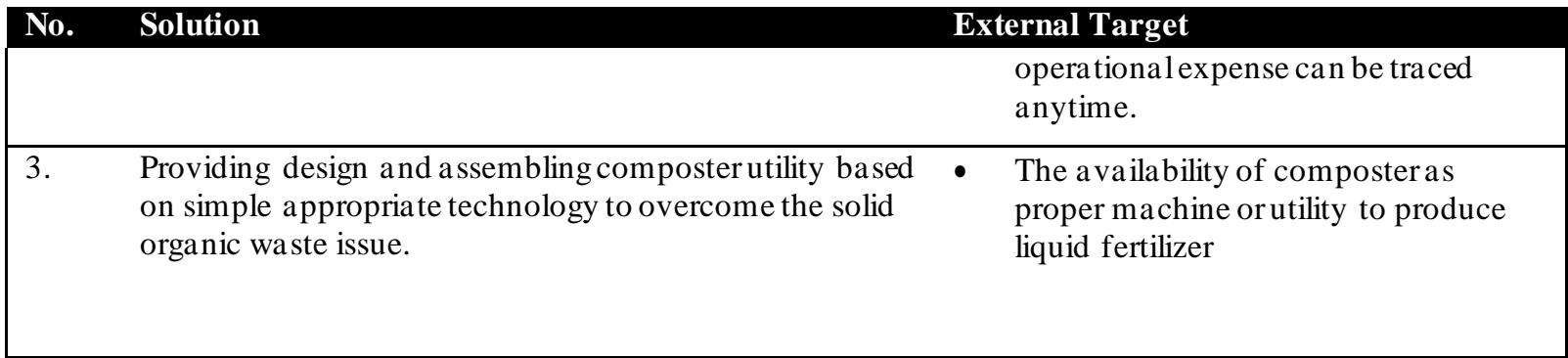

\section{The Preparation of Program Execution}

Before the initiation of all activities, socializations related to this program are executed based on the procedure coordinated with authorized parties thus the program can start and run properly. Bumi Hijau Cemerlang waste bank team expect that this socialization will get support from all so then the result can reach the desired target from both parties (lecturer team from Mercu Buana University and Bumi Hijau Cemerlang waste bank team).

\section{RESEARCHMETHODS TheSteps of Performance}

In order to provide solution towards the issues faced by Bumi Hijau Cemerlang waste bank team, the steps are arranged as shown in Table 2. Evaluation and Achievement and continuity of program in every step of learning, eventually evaluation will be carried out as basis of feedback to ensure the sustainability between the team and customers (Eman Suherman, 2008).

Table 3 Outcomes

\begin{tabular}{|l|l|l|l|}
\hline \multicolumn{4}{|c|}{ Outcomes } \\
\hline \multicolumn{1}{|c|}{ Step I } & \multicolumn{1}{|c|}{ Step II } & \multicolumn{1}{c|}{ Step III } & \multicolumn{1}{c|}{ Step IV } \\
\hline $\begin{array}{l}\text { Waste bank team } \\
\text { can do and } \\
\text { develop inorganic } \\
\text { waste recycle. }\end{array}$ & $\begin{array}{l}\text { Implementing the } \\
\text { learning module } \\
\text { handicraft from } \\
\text { waste recycle } \\
\text { learning module } \\
\text { with procedural } \\
\text { consistency. }\end{array}$ & $\begin{array}{l}\text { Carrying out the } \\
\text { learning of } \\
\text { management to } \\
\text { increase the } \\
\text { selling value and } \\
\text { accounting skill }\end{array}$ & \\
& & \\
\hline
\end{tabular}

Source: Researcher's Concept, 2019

\section{FINDINGS AND DISCUSSION}

\section{The Result Achievement}

\section{Learning and Training to Develop Inorganic Waste Recycle (Plastic)}

All this time the endeavor to use the plastic waste has not conducted yet by Bumi Hijau Cemerlang waste bank team. The leader of waste bank, Mrs. Silvana Tobing stated that so far the team does the activity to collect the waste on six location spots at the same time from 9 am until 1 $\mathrm{pm}$, where this activity is carried out in every two weeks which resulting in $200-500 \mathrm{~kg}$ waste stack that consists of inorganic waste (plastic, paper, plastic bottle, etc.). Then the waste will be sold to the scavenger or collector with cheap price).

The waste bank team indeed they desire to recycle the waste to make it as better product which has high economic value, potential in benefit and become earning field for the unemployed housewives to recycle the waste together and get income. Besides, this activity is conducted to support minimalizing the waste so the environment can be clean and healthy. The problems faced 
by the Mercu Buana University team will invite the expert to train how to recycle waste especially plastic waste to be made as artificial sunflower and other plants. Regarding to the Corona pandemic recently, the training is held on zoom virtual meeting also using vid eo for learning to ease the waste bank team to follow the steps to recycle plastic waste, as seen on picture 2, the activity of handmade craft making process. In this learning, there are two modules of tutorial from the trainer. The module 1 is recycling the plastic waste to be Aglonema leave and module 2 recycling the plastic waste to make sunflower. The plastic waste product recycle is ready to use produce artificial sunflower and Aglonema leaves that only need wire, glue and scissor to produce new items to be then sold.

\section{Training and Learning of Financial Report Making}

The purpose of this learning is aimed that waste bank team is able to make financial report and can run the business well so then the loss and benefit can be analyzed. The right financial report is ideally initiated from the beginning of the business activity thus other parties and internal parties can appraise or assess the value of the business. There are several steps to ease the financial control, those are stated as below; (1) Gathering and jotting down all transactions on accounting journal, (2) Gathering all needed data to make adjustment journal (3) Making financial report.

The result of learning of this training is the improvement of new insight that is obtained by waste bank team who they do not know before, especially about how to make simple report. In ord er to ease the comprehension regarding to this issue, researcher team of Mercu Buana University make module about how to make simple report. On picture 4.12, learning and training is given by economy expert to the Bumi Hijau Cemerlang waste bank leader and the vice of leader. It is expected that this learning can be shared to all members of Bumi Hijau Cemerlang, waste team. Next, the training will be given to some other members of Bumi Hijau Cemerlang waste bank team.

The community service activity performed by lecturer team of Mercu Buana University is followed by another step, those are:

1) Providing socialization about how to do better ad ministration which is easy to understand and learning about sales management to market the profitable products from waste recycle (liquid fertilizer).

2) Checking and controlling the Bumi Hijau Cemerlang waste bank team gradually (once in a month) regarding to the recycle production development, ad ministration and marketing.

3) Controlling the Bumi Hijau Cemerlang waste bank team gradually (once in a month) in order to minimize the organic waste of household which gives impact to the cleaner and healthier environment and can produce liquid fertilizer which as economic value and profitable.

\section{The Development of Liquid Fertilizer from Organic Waste}

The result of survey conducted by Mercu Buana University team, where the Bumi Hijau Cemerlang waste bank team complain about the issue of handling the household organic waste which are the skin of fruits and vegetable remnants that cannot be maximize due to lack of the 60 liters composter with improper condition, thus the waste can only be use partially. Based on this problem, the Mercu Buana University team will make the composter machine that is more effective and more affordable in order to produce liquid fertilizer with better quality and can be used by the residents or hou seholds that keen on planting. Based on the information derived from the leader of Bumi hijau Cemerlang waste bank team, it is known that there a lot of field in surrounding of Korpri Complex where many damaged uninhabited houses can be used for planting or gardening thus the unused field can be fecund and productive grow the daily needs. They plan to grow papaya, 
corn, vegetables, chili, tomatoes, ginger, etc. This can be seen on Picture 3 below that shows the socialization regarding to the use of composter to produce liquid fertilizer from organic waste.

The liquid fertilizer made from organic waste is profitable in economic side and definitely reduce the stack of waste which then make the environment cleaner and healthier. One of the examples is shown on Picture 3, in the houses of Bumi Hijau Cemerlang waste bank team they use the said liquid fertilizer. Despite of the hard times as Corona Virus pandemic existence, the Bumi Hijau Cemerlang waste bank team members are feisty to continue their work to handle and collect waste as vegetable remnant, rotten fruits and other kinds of organic waste. The researcher team provides 4 sets of composter machine, where these machines are given to the leader of Bumi Hijau Cemerlang waste bank team. And will be distributed to some people as representative of Neighborhood who will take responsibility to direct the society in each area thus, they can used to put their organic waste from kitchen to be collected and processed as liquid fertilizer. The liquid fertilizer can be used by the society to fertilize and if the stock is excessive, then the liquid fertilizer will be sold in to get income for RW cash money saving. This is has positive impact in economic side which can gets higher gradually.

\section{CONCLUSION AND RECOMMENDATION}

Waste bank has purpose to improve the knowledge to gain awareness and concern of society regarding to the issue of waste management which has direct and indirect impacts in constructing clean, healthy and comfortable life alongside with bettering the economic side related to the earning for wand society. The impact for the society can be described as below:

1. Reducing the waste disposed to the landfills (the disposal of waste materials by burial).

2. Contributing in reducing the air pollution as the cause of waste or trash burn.

3. Contributing to construct the healthy and clean environment.

4. Educational aspects;

a) Cultivating the importance of managing the household waste to the society and giving understanding that the waste can be recycled and made as community trade which led into profit in money. Then the money can be invested.

b) Education of environment in early age and not to leave them or let them

c) Children can get the importance and comprehension of money saving.

d) Children can give value to the waste they have or they dispose

5. Social and Economic Aspects;

a) Gaining the family earning from the waste they dispose in waste bank.

b) Creating entrepreneurship sense regarding to the waste management in society.

c) Changing the negative perspective in society about the waste activists especially scavengers.

\section{BIBLIOGRAPHY}

Arwati, I Gusti Ayu., Saparina, Euis Nina ., Wuryandari, Nur Endah Retno., 2020. Overcoming Obstacles In The Development Of Ikrt / Umk Through Application Of Appropriate Technology. https://dinastipub.org/DIJDBM E-ISSN : 2715-4203, P-ISSN : 2715419X Volume 1, Issue 3, April 2020

Bishop, M dan Rebecca, B. 2008. Disabling Accounting, Elsevier, Critical Perspective on Accounting, 19 1-16.

Dika, Agustus. 2017 September 2018 Bank Sampah Dan TPS 3R Kurangi Pembuangan Ke TPA Tanggerang Kota .go.id Liputan6.com, Tangerang. 
Dwiaji, Yudhi Chandra., Nurato , Hanum, Bethriza., 2017 . IBM Karang Taruna dan PKK Desa Kohod Pakuhaji Melalui Peningkatan Nilai Tambah Dalam Pengolahan Limbah Kelapa Sebagai Upaya Peningkatan Pendapatan Masyarakat. Adiwidya, Volume I Nomor 1 - November

Eman, Suherman., 2008: Desain Pembelajaran Kewirausahaan, Alfabeta Bandung

Fernández, J. Castro, 2018. Influence Of Controllable Variables On The Composting Process, Kinetic, And Maturity Of Stevia Rebaudiana Residues. International Journal of Recycling of Organic Waste in Agriculture (2018) 7:277-286 https://doi.org/10.1007/s40093-018-0214-X

Gleen, Lehman., 2004, Accounting, Accountability And Religion: Charles Taylor's Catholic Modernity And The Malaise of A Disenchanted World, The fourth Asia Pacific Interd isciplinary Research In Accounting, Conference, Singapore.

Hasibuan, Sarwani., Mirza, dan Zulfa Fitri Ikatrinasari, 2017. Creativity Product Of PKK South Meruya Womans Based On 3r Urban Solid Waste. Jurnal Sinergitas PkM \& CSR Vol.2, No.1,

Nunes, Ramom Rachide. 2018. Vermi Composted Tannery Wastes Organic Cultivation Of Sweet Pepper: Growth, Nutritive Value And Production International, Journal Recycling of Organic Waste in Agriculture . 7:313-324 https://doi.org/10.1007/s40093- 018- 02177

Nurjazuli, Asti Awiyatul, Cut Juliana, Kartika Dian Pertiwi, Kholilah Samosir, Putrie Prasetyawati, Santri Pertiwi. 2016. Teknologi Pengolahan Sampah Organik Menjadi Kompos Cair,. Seminar Nasional Sains dan Teknologi Lingkungan II Padang, 19 Oktober . 